\title{
Frequency of QT Interval Prolongation in Chronic Liver Disease Patients
}

${ }^{1}$ Wali Khan, ${ }^{2}$ Tahir Ullah Khan, ${ }^{3}$ Muzaffar Mehdi, ${ }^{3}$ Adnan Salim

${ }^{1}$ Department of Hepatobiliary \& Liver Transplant Surgery, Shaikh Zayed Medical Complex, Lahore

${ }^{2}$ Department of Medicine, Shalamar Hospital, Lahore

${ }^{3}$ Department of Gastroenterology, Shaikh Zayed Medical Complex, Lahore

\begin{abstract}
Introduction: The frequency of QT interval prolongation as published in the international and local literature has been variable. Aims \& Objectives: To determine the frequency of QT interval prolongation in patients with chronic liver disease and resolve the variability in the literature. Place and duration of study: The present study was conducted in Gastroenterology and Hepatology Unit Shaikh Zayed Hospital Lahore from $1^{\text {st }}$ March 2017 to $31^{\text {st }}$ August 2017. Material \& Methods: About 240 patients with diagnosed chronic liver disease were selected. Electrocardiography (12 lead) was performed in all patients to look for QT interval prolongation and their mean was calculated for purpose of analysis. Results: Mean age of our patients was $53.7 \pm 11.9$ and male gender was dominant (55.8\%). It was noted that QT interval was prolonged in 62 patients (25.8\%) while rest of the 178 patients had normal QT interval. Conclusion: QT interval prolongation is frequently observed (25.8\%) in chronic liver disease patients. Therefore, every patient with chronic liver disease should be investigated for QT interval prolongation.
\end{abstract}

Key words: Chronic liver disease, QT interval, Electrocardiography

\section{INTRODUCTION}

$\mathrm{C}$ hronic liver disease refers to chronic disturbance of liver function characterized by distortion of the normal liver architecture and replacement by nodular regeneration and fibrosis. It is widely prevalent in Europe and contributes about 1.5 to $2 \%$ of overall mortality in the region. ${ }^{1}$ It ranks $10^{\text {th }}$ among the leading causes of death in United States, but even this high mortality is thought to be an underestimation and more research is needed. ${ }^{2}$

Chronic liver disease and its complications contribute to a significant burden of disease in Pakistan, resulting in loss of precious lives and an enormous health care cost. Despite being highly prevalent, the effects of chronic liver disease on cardiovascular system have not been studied in detail till yet and this important aspect continues to be neglected from health care professionals all over the world. Though patients with chronic liver disease have increased baseline cardiac output, but their ventricular response to physiological and pharmacological stress is suboptimal. This phenomenon is termed as cirrhotic cardiomyopathy. ${ }^{3,4,5}$ Pathophysiologically, this condition is thought to be due to abnormal functioning of cardiac beta receptors, myocyte hypertrophy and fibrosis and channelopathies. ${ }^{6}$

Data regarding actual prevalence of cirrhotic cardiomyopathy in patients with chronic liver disease is very limited, primarily because function of myocardium in this condition remains optimal until it is faced with stress. According to an estimate, about $50 \%$ patients with chronic liver disease planned to undergo hepatic transplantation had some element of myocardial dysfunction with $7-21 \%$ dying of heart failure after liver transplantation. ${ }^{7,8}$ This cardiac dysfunction may also adversely affect the prognosis of the patient, especially when undergoing invasive procedures such as Transjugular Intrahepatic Portosystemic Shunt (TIPS), surgery or liver transplantation. ${ }^{9,10}$ The frequency of QT interval prolongation in cirrhotic patients is $30-60 \%$ and correlates positively with the severity of chronic liver disease ${ }^{11}$.

Though, symptomatology of cirrhotic cardiomyopathy may improve with beta blockers and potassium sparing diuretics, but definite treatment is liver transplantation. ${ }^{12}$ It is vital to diagnose cirrhotic cardiomyopathy at an early stage because it ultimately contributes to more serious 
complication of chronic liver disease like hepatorenal and hepatopulmonary syndromes. ${ }^{13}$ Brain natriuretic peptide can help in early diagnosis of this condition, but the most common and least expensive method is to look for QT interval prolongation on electrocardiogram. ${ }^{14,15,16}$ Frequency of QT interval prolongation in chronic liver disease as published in literature has been different ranging from 20 to $40 \%{ }^{17}$

The rationale of our study is to deal with the controversy existing in local and international literature regarding frequency of QT interval prolongation in chronic liver disease patients. Furthermore, this study will make us realize the importance of ECG in cirrhotic patients to diagnose cirrhotic cardiomyopathy at an early stage, so that early management decisions can be taken.

\section{MATERIAL AND METHODS}

The present study was conducted in Gastroenterology and Hepatology Unit Shaikh Zayed Hospital Lahore from $1^{\text {st }}$ March to $31^{\text {st }}$ August 2017 involving about 240 chronic liver disease patients. Confidence interval was selected as $95 \%$ with 5\% margin of error. Sample size was calculated using WHO formula and sampling was done via non probability purposive sampling method. Patients included in our study were of both genders, aged more than 18 years, and having chronic liver disease secondary to chronic viral hepatitis $\mathrm{C}$ or B.

Patients excluded were those having electrolyte imbalance (potassium and calcium), those using drugs causing QT interval prolongation (ca channel blockers, Beta blockers, macrolides, antihistamines, quinolones, amiodarone), and those having diseases causing QT interval prolongation (conduction defects, atrial fibrillation, hypertension, ischemic heart disease). After obtaining written informed consent from patients, electrocardiography was performed in all patients to assess for QT interval prolongation. Corrected QT interval was measured for three different leads and their mean value was calculated for purpose of analysis. QT interval more than 0.44 seconds was labeled as prolonged QT interval. The findings were noted on a proforma.

\section{Statistical analysis:}

Data was entered and analyzed via SPSS version 23. Qualitative variables were expressed in the form of frequency and percentages while quantitative variables were expressed in the form of mean $\pm \mathrm{SD}$.

\section{RESULTS}

The mean age of study population was $53.7 \pm 11.9$ years with predominant age range of 51 to 60 years $(35 \%)$, followed by age range of 41 to 50 years $(29.6 \%)$ (Table-1). Overall, male gender was dominant in our study (57\%) (Table-2). About 150 patients $(62.5 \%)$ were having chronic liver disease secondary to hepatitis $\mathrm{C}$ and 90 patients (37.5\%) were having chronic hepatitis B. Regarding corrected QT interval, mean QT interval was $0.44 \pm 0.057$ seconds. About 178 patients (74.2\%) were those with normal QT interval and 62 patients (25.8\%) were having prolonged QT interval $(>0.44$ seconds) (Table-3). Distribution of chronic liver disease patients in terms of gender and child Pugh scoring is shown in Table-4 \& 5 .

\begin{tabular}{|c|c|}
\hline Age Range (Years) & Number of Patients (\%) \\
\hline 20 To 30 & $8(3.3)$ \\
\hline 31 To 40 & $24(10.00 \%)$ \\
\hline 41 To 50 & $71(29.6 \%)$ \\
\hline 51 To 60 & $84(35 \%)$ \\
\hline 61 To 70 & $38(15.8 \%)$ \\
\hline 71 To 80 & $15(6.3 \%)$ \\
\hline
\end{tabular}

Table-1: Distribution of patients by age range

\begin{tabular}{|c|c|c|}
\hline Gender & No. of Patients & Percentage \\
\hline Male & 137 & $57 \%$ \\
\hline Female & 103 & $43 \%$ \\
\hline Total & 240 & $100 \%$ \\
\hline
\end{tabular}

Table-2: Distribution of Patients by Gender

\begin{tabular}{|c|c|c|c|}
\hline $\begin{array}{c}\text { Corrected QT } \\
\text { Intyerval (QTC) }\end{array}$ & $\begin{array}{c}\text { Number of } \\
\text { Patients }\end{array}$ & Percentage & P Value \\
\hline$<0.44$ Seconds & 178 & $74.2 \%$ & 0.003 \\
\hline$>0.44$ Seconds & 62 & $25.8 \%$ & 0.004 \\
\hline Total & 240 & $100 \%$ & \\
\hline
\end{tabular}

Table-3: Distribution of Patients by corrected QT interval

\begin{tabular}{|l|c|c|c|}
\hline $\begin{array}{c}\text { Child Pugh } \\
\text { Score }\end{array}$ & $\begin{array}{c}\text { Number of } \\
\text { Patients }\end{array}$ & $\begin{array}{c}\text { Mean QT } \\
\text { Interval }\end{array}$ & $\begin{array}{c}\text { Standard } \\
\text { Deviation }\end{array}$ \\
\hline Class A & 24 & $466.87 \mathrm{msec}$ & 27.35 \\
\hline Class B & 90 & $452.78 \mathrm{msec}$ & 25.83 \\
\hline Class C & 126 & $463.65 \mathrm{msec}$ & 19.67 \\
\hline
\end{tabular}

Table-4:Distribution of Patients with Liver Cirrhosis according to the Child-Pugh class and QT Interval 


\begin{tabular}{|c|c|c|c|c|}
\hline $\begin{array}{c}\text { Child Pugh } \\
\text { Score }\end{array}$ & Child A & Child B & Child C & Total \\
\hline Women & $\begin{array}{c}16 \\
(16 \%)\end{array}$ & $\begin{array}{c}39 \\
(38 \%)\end{array}$ & $\begin{array}{c}48 \\
(46 \%)\end{array}$ & $\begin{array}{c}103 \\
(43 \%)\end{array}$ \\
\hline Men & $\begin{array}{c}20 \\
(15 \%)\end{array}$ & $\begin{array}{c}47 \\
(35 \%)\end{array}$ & $\begin{array}{c}70 \\
(50 \%)\end{array}$ & $\begin{array}{c}137 \\
(57 \%)\end{array}$ \\
\hline Total & 36 & 86 & 118 & $\begin{array}{c}240 \\
(100 \%)\end{array}$ \\
\hline
\end{tabular}

Table-5: Distribution of patients with liver cirrhosis according to the Child-Pugh class and gender

\section{DISCUSSION}

Impact of chronic liver disease on cardiovascular system in human body is least discussed and this important aspect continues to be neglected from health care providers even in modern times. Although the cardiovascular changes in chronic liver disease patients cover a wide spectrum, but the most important finding in these patients is prolongation of the QT interval. ${ }^{18,19}$ In the present study, the frequency of QT interval prolongation was $25.8 \%$. These results were comparable to a study conducted by Bhatti and his colleagues who found the frequency of QT interval prolongation to be $24.7 \% .{ }^{20}$ Zuberi and his colleagues compared the QT interval and heart rate in cirrhotic patients with non-cirrhotic patients and found that frequency of QT interval prolongation was significantly high in cirrhotic group as compared to non-cirrhotic patients $(19.2 \%) .{ }^{21}$ Similarly, Kosar and his team focused on correlating QT interval prolongation with severity and overall prognosis of liver disease. They noted that about $32 \%$ patients with liver cirrhosis had QT interval prolongation in comparison to only $5.7 \%$ (p value $<0.001$ ) in healthy controls. ${ }^{22}$ Another study carried out by Henriksen and his colleagues further strengthened the association between QT interval prolongation and chronic liver disease. They noted that frequency of QT interval prolongation in cirrhotic patients was $37 \%$ as compared to controls ( $p$ value $<0.03$ ). These results were slightly higher in comparison to our study results. ${ }^{23}$ According to research data from Agha Khan Hospital Karachi, about $35 \%$ of cirrhotic patients had QT prolongation, but their study differed from our study in the sense that they focused on other electrophysiological changes (PR interval, QRS duration) too. ${ }^{24}$ In another study, about $68.8 \%$ cirrhotic patients were known to have prolonged QT interval. ${ }^{25}$ The major limitation of our study was that baseline ECG was not available in most of our patients and we were not able to establish a normal cardiac status before the onset of cirrhosis.

\section{CONCLUSION}

It was concluded from our study that a significant number $(25.8 \%)$ of chronic liver disease patients have evidence of cirrhotic cardiomyopathy manifested by prolong QT interval. Therefore, every patient with liver cirrhosis should be investigated for QT interval prolongation.

\section{Acknowledgments:}

We thank our colleagues from Gastroenterology and Hepatology Unit Shaikh Zayed Hospital Lahore, who provided insight and expertise that greatly assisted our research, although they may not agree with all the interpretations of this research article. We would also like to give our special thanks to Professor Altaf Alam and Professor Arshal Kamal Butt for their immense cooperation and guidance in improving the manuscript.

\section{REFERENCES}

1. Kheloufi F, Frankel D, Kaspi E, Lepelley M, Mallaret M, Boucherie Q, Roll P, Micallef Blachier M, Leleu H, Peck-Radosavljevic M, Valla DC, Roudot-Thoraval F (2013) The burden of liver disease in Europe: a review of available epidemiological data. J Hepatol 58:593-608

2. Asrani SK, Larson JJ, Yawn B, Therneau TM, Kim WR (2013) Underestimation of liverrelated mortality in the United States. Gastroenterology 145: 375-382.

3. Saleh AA, Tamer RF, Samuel SL. Cirrhotic cardiomyopathy. Semin Liver Dis 2008;28:59-69.

4. Wong F.Cirrhotic cardiomyopathy. J Hepatol Int. 2009; 3:294-304.

5. Moller S, Henriksen JH.Cirrhotic cardiomyopathy. J Hepatol 2010; 53:179-90

6. Altayar O1, Lisker-Melman M2.Physiologic Adaptation or Cirrhotic Cardiomyopathy: It is Time for New Definitions! J Card Fail. 2019; Mar; 25(3):173-175.

7. Zardi EM, Abbate A, Zardi DM, Dobrina A, Margiotta D, Van Tassell BW, et al. Cirrhotic cardiomyopathy. J Am CollCardiol. 2010; 56:539-549.

8. Myers RP, Lee SS. Cirrhotic cardiomyopathy and liver transplantation. Liver Transpl. 2000: S44-S52.

9. Bernardi M, Calandra S, Colantoni A, Trevisani F, Raimondo ML, Sica G et al. Q-T interval prolongation in cirrhosis: prevalence, relationship with severity, and etiology of the 
disease and possible pathogenetic factors. Hepatology. 1998; 27:28-34.

10. Rabie, R.N., Cazzaniga, M., Salerno, F., and Wong, $\mathrm{F}$. The use of E/A ratio as a predictor of outcome in cirrhotic patients treated with transjugular in trahepatic portosystemic shunt. Am J Gastroenterol. 2009; 104:2458-2466.

11. Gaskari S, Honar H, Lee SS. Therapy insight: cirrhotic cardiomyopathy. Nat ClinPrat Gastroenterol Hepathol. 2006; 3:329-337.

12. Al-Hamoudi W, Lee SS. Cirrhotic cardiomyopathy. Ann Hepatol 2006; 5:132-9.

13. Al-Hamoudi WK. Cardiovascular changes in cirrhosis: pathogenesis and clinical implications. Saudi J Gastroenterol 2010; 16:145-53.

14. Pimenta J, Paulo C, Gomes A, Silva S, Rocha GF, Bettencourt P. B-type natriuretic peptide is related to cardiac function and prognosis in hospitalized patients with decompensated cirrhosis. Liver Int 2010; 30:1059-66.

15. Zambruni A, Di-Micoli A, Lubisco A, Domenicali M, Trevesani F, Bernardi M, et al. QT interval correction in patients with cirrhosis. J Cardiovasc Electrophysiol 2007; 18:77-82.

16. Zambruni A, Trevisani F, Caraceni $P$, Bernardim M. Cardiac electrophysiological abnormalities in patients with cirrhosis. J Hepatol 2006; 44: 994-1002.

17. Bernardi M, Maggioli C, Dibra V, Zaccherini G. QT interval prolongation in liver cirrhosis: Innocent bystander or serious threat? Expert Rev Gastroenterol Hepatol. 2012 Feb ;6(1):57-66

18. Ytting H, Henriksen JH, Fuglsang S, Bendtsen $\mathrm{F}$ and Moller S. Prolonged QT interval in mild portal hypertensive cirrhosis. J Hepatol 2005; 43:637-44.

19. Zambrumi A, Trevisani F, Caraceni $P$ and Bernardi M. Cardiac electrophysiolosical abnormalities in patients with cirrhosis. J Hepatol 2006; 44:994-1002.

20. Bhatti BA, Ali F, Satti AS. Prolonged QTc interval is an electrophysiological hallmark of cirrhotic cardiomyopathy. Open J Int Med 2014; 4:33-39

21. Zuberi BF, Ahmed S, Faisal N, Afsar S, Memon AR, Baloch I, et al. Comparison of heart rate and QTc duration in patients of cirrhosis of liver with non-cirrhotic controls. J Coll Physicians Surg Pak 2007; 17: 69-71.
22. Kosar F, Ates F, Sahin I, Karincaoglu M, Yildirim B. QT interval analysis in patients with chronic liver disease: a prospective study. Angiology 2007; 58:218-24.

23. Henriksen JH, Fuglsang S, Bendtsen F, Christensen E, Moller S. Dyssynchronous electrical and mechanical systole in patients with cirrhosis. J Hepatol 2002; 36:513-20.

24. Parkash O, Mohyuddin GR, Ayub A, Nazir I, Maan AA, Hamid S. Electrophysiological changes in patients with liver cirrhosis in a tertiary care hospital in Karachi, Pakistan. J Ayub Med Coll Abbottabad. 2016 Oct-Dec; 28(4):676-679.

25. Barbosa M, Guardado J, Marinho C, Rosa B, Quelhas I, Lourenço A, Cotter J. Cirrhotic cardiomyopathy: Isn't stress evaluation always required for the diagnosis? World J Hepatol. 2016 Jan 28; 8(3):200-6.

\section{The Authors:}

Dr. Wali Khan

Senior Registrar,

Department of Hepatobiliary \& Liver

Transplant Surgery,

Shaikh Zayed Medical Complex, Lahore.

Dr. Tahir Ullah Khan

Senior Registrar,

Department of Medicine,

Shalamar Hospital, Lahore.

Dr. Muzaffar Mehdi

Senior Registrar,

Department of Gastroenterology,

Shaikh Zayed Medical Complex, Lahore.

Dr. Adnan Salim

Assistant Professor,

Department of Gastroenterology,

Shaikh Zayed Medical Complex, Lahore.

\section{Corresponding Author:}

Dr. Wali Khan

Senior Registrar,

Department of Hepatobiliary \& Liver

Transplant Surgery,

Shaikh Zayed Medical Complex, Lahore.

E-mail: dr_wali84@yahoo.com 